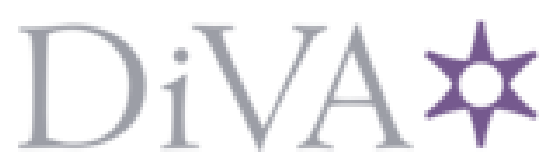

http://www.diva-portal.org

\title{
Postprint
}

This is the accepted version of a paper published in Journal of Small Business and Enterprise Development. This paper has been peer-reviewed but does not include the final publisher proofcorrections or journal pagination.

Citation for the original published paper (version of record):

Andersén, J., Ljungkvist, T., Svensson, L. (2015)

Entrepreneurially oriented in what? A business model approach to entrepreneurship.

Journal of Small Business and Enterprise Development, 22(3): 433-449

http://dx.doi.org/10.1108/JSBED-11-2013-0170

Access to the published version may require subscription.

N.B. When citing this work, cite the original published paper.

This article is (c) Emerald Group Publishing and permission has been granted for this version to appear here (http://dx.doi.org/10.1108/JSBED-11-2013-0170). Emerald does not grant permission for this article to be further copied/distributed or hosted elsewhere without the express permission from Emerald Group Publishing Limited.

Permanent link to this version:

http://urn.kb.se/resolve?urn=urn:nbn:se:his:diva-11322 


\title{
Entrepreneurially oriented in what? A business model approach
}

\section{to entrepreneurship}

\begin{abstract}
Purpose:

The aim of this article is to illustrate and argue for the necessity of deconstructing the entrepreneurship concept by analyzing entrepreneurial orientation (EO) at various levels of the business model.

Design/methodology/approach:

Literature review supplemented with five illustrative cases.

Findings:

A business model approach to entrepreneurship enables identification of the component of the business model in which entrepreneurship was started. This has several implications for analysis of the EO-performance relationship and for the identification of antecedents to EO.

\section{Originality/value:}

The EO of firms has generally been analyzed at a generic level, i.e. the concept has been used to measure and analyze the overall entrepreneurship of firms. In this paper, we argue that EO can be present in various dimensions of a business and that firms can be entrepreneurial in certain areas and conservative in other areas.
\end{abstract}




\section{Introduction}

Entrepreneurship is generally considered to be a highly aggregated concept. For example, firms are often described as being bureaucratic or entrepreneurial (Miller and Friesen, 1982) managers are classified as entrepreneurial or conservative (Covin and Slevin, 2007) and strategies can be regarded as entrepreneurial or non-entrepreneurial (Dess et al., 1997). Thus, the concept of entrepreneurship is often used to describe the general characteristics of, for example, firms, managers, and/or strategies. This is also representative of the widely used concept of entrepreneurial orientation (EO) (Covin and Slevin, 1989; Miller and Friesen, 1982), i.e. the most common method of measuring entrepreneurship. EO has been defined in several ways (e.g. Smart and Conant, 1994; Zahra, 1991), and features such as autonomy and competitive aggressiveness (Lumpkin and Dess, 1996) have been used to measure it.

However, the most common definition of EO is the propensity of a firm to take risks, to be innovative, and to be proactive (Covin et al., 2006; Wiklund and Shepherd, 2003). These dimensions of entrepreneurship also reflect the aggregated nature of the concept of entrepreneurship. When EO is delimited to certain business areas, it is often used to describe entrepreneurial activities in the product market (Miller and Friesen, 1982) in terms of, for example, new entry (Lumpkin and Dess, 1996).

Thus, the established definition of EO does not indicate or describe whether an entrepreneurial firm is entrepreneurial in all of its activities or whether the entrepreneurial mindset is only reflected in some specific area of the business. Alternatively, entrepreneurship may be restricted to activities in the product market. Some efforts have, however, been made to describe entrepreneurial activities in specific business areas. Entrepreneurial marketing (Hills et al., 2007; Morris et al., 2002; Stokes, 2000) has, for example, been used to describe entrepreneurship in a marketing context. This concept is often defined as involving innovative, risk-taking, and proactive marketing techniques (Morris et al., 2002) and can be 
regarded as an effort to apply the concept of EO to marketing practices. Other examples of entrepreneurship in specific domains are entrepreneurial management of alliances (Sarkar et al., 2001), entrepreneurial pricing practices (Schindehutte and Morris, 2001), and entrepreneurship in an international context (McDougall and Oviatt, 2000).

If firms can be entrepreneurial in these areas, however, other firms are likely to be entrepreneurial in other specific areas. This does not necessarily imply that these firms are entrepreneurial in all areas. In this article, we will argue that firms can be entrepreneurially oriented in certain areas of their business while at the same time being highly conservative in other areas. For example, some companies can be entrepreneurial in their marketing activities but conservative in product development, while others can be risk-taking and innovative in their product development but quite cautious regarding resource acquisitions in terms of employing new personnel. This deconstructed approach to entrepreneurship has rarely been discussed in contemporary entrepreneurship research. Thus, we will argue for the necessity of looking beyond both the generic and the external (i.e. product market) approach to EO.

One way of analyzing various aspects of a firm, and thereby understanding different dimensions of entrepreneurship, is to use the concept of business models. Although business models have been used in strategic management research (e.g. Zott and Amit, 2008) and in entrepreneurship research (George and Bock, 2011), the concept of business model appears more frequently in practice than in scholarly publications (George and Bock, 2011; Morris et al., 2005). Even so, business models can be a useful framework when analyzing various aspects of a firm. This holistic approach can enable analysis of all imperative aspects of a firm, thereby allowing the identification of various areas that can be analyzed using the entrepreneurial-“non-entrepreneurial” continuum. Thus, the aim of this article is to illustrate and argue for the necessity of deconstructing the entrepreneurship concept by analyzing EO at various levels of the business model. 
The remainder of this article is organized as follows. Initially, we discuss EO and how the concept has been defined. After the discussion regarding EO, we review and define the concept of business models. Then we discuss entrepreneurship in various dimensions of the business model. This is followed by some illustrative examples of how companies have been entrepreneurial and/or conservative in the different components of the business model, which illustrates the usefulness of analyzing EO from a business model approach. Lastly, we discuss the implications, limitations, and conclusions of the study.

\section{Entrepreneurial Orientation; Definition of Context(s)}

The concept of EO has been used to measure the level of entrepreneurship, i.e. how entrepreneurial firms or managers actually are. Entrepreneurially oriented firms are generally characterized by actions (or management style, posture, behavior, strategies etc., depending on the definition) that are autonomous, innovative, risk-taking, proactive, and aggressive towards competitors (Covin and Slevin, 1989; Miller and Friesen, 1982). Some studies (e.g. Voss et al., 2005) include all these dimensions in the definition of EO and others (e.g. Wiklund and Shepherd, 2003) include three of them, i.e. innovativeness, risk-taking, and proactiveness. However, which elements should be included is not a controversial issue in EO research. An aspect of EO that has been rarely discussed-but most likely often implicitly taken for granted - is the areas of the business in which EO can be manifested. In their recent review of EO, Covin and Wales (2012) listed a number of definitions of EO that can be used to illustrate this often overlooked element of it. Based on their compilation, it is possible to identify mainly two context definitions of EO: (1) the external context in terms of the product market and (2) a more generic context, i.e. all aspects of the business. Expressions such as “...that lead to new entry” (Lumpkin and Dess, 1996, p.136) and “...product market strategies" (Miller and Friesen, 1982, p.5) are examples of the externally-oriented definition, whereas statements such as "...change in the organization or marketplace" (Voss et al., 2005, 
p.1134) and "behaviors that have the qualities" (Pearce et al., 2009, p.219) are examples of more generic definitions of EO. These dimensions are also reflected in the most common method of measuring EO, i.e. the scale developed by Miller and Friesen (1982) and refined by Covin and Slevin (1989) (Andersén, 2010; Lumpkin and Dess, 1996). Three of the nine items for measurement of EO according to this scale are externally-oriented (those that concern proactiveness) whereas six items are generic or not specific to any dimension of the business.

Thus, although few studies have discussed the context in which the concept of EO should be applied, we have identified the generic application and the external application as being the most common in the literature. However, both of these definitions have some important limitations. Let us assume that a company is highly innovative and successful in its efforts to reduce production costs. The company has achieved this by recruiting highly-skilled personnel and investing in state of the art production facilities. In doing so, the company has been able to implement a low-price market strategy and gain market share. This company took a risk by being innovative and proactive in its investments in human and technological resources. But can the company be regarded as being entrepreneurially oriented if we use the externally-oriented definition of EO? Although the new offering in the product market can be defined as being proactive, the company's endeavors in the product market can hardly be regarded as innovative or risk-taking. Thus, the launch of new products produced at a lower cost—rather than other products — on the market is not entrepreneurial. Consequently, if EO is defined as involving risk-taking, innovative, and proactive behavior in the product market, this particular company cannot be regarded as an entrepreneurially oriented company. Using the generic definition of EO makes it more difficult to decide whether or not to label such a company as entrepreneurial. Although the company can be regarded as highly entrepreneurial in its efforts to reduce production costs, it is not entrepreneurial in its activities in the product market. In order to be entrepreneurial according to the generic approach of EO, it is doubtful 
whether firms can be highly entrepreneurial in certain areas of their business while simultaneously being highly conservative in most other areas. Also, if we use the established scale for measurement of EO (Covin and Slevin, 1989; Miller and Friesen, 1982), this particular company would not be regarded as being entrepreneurial.

To summarize, neither the external approach nor the generic approach to EO respects the notion that firms can be entrepreneurial in some aspects of their business and conservative in other aspects. Some streams of research have discussed entrepreneurship in delimited areas of a company's operations_-for example, entrepreneurial marketing (Hills et al., 2007), entrepreneurial alliance management (Sarkar et al., 2001), and entrepreneurial pricing practices (Schindehutte and Morris, 2001). However, few studies have analyzed EO in several specific dimensions of a business. Thus, when discussing EO we are faced with two key questions: (1) How entrepreneurial is a company, i.e. what is the level of risk-taking etc.? (2) In which areas is the company entrepreneurial? The business model concept provides a holistic approach to organizations and can therefore constitute a useful framework for analyzing various business dimensions. So let us review some relevant literature on business models in order to identify a useful definition of a business model.

\section{Business Models}

Although all companies have a business model, whether expressed or not, there is still no unified description of the concept. Instead, the research field is characterized by differences and definitions that reflect different meanings and significances (Osterwalder et al., 2005; Shafer et al., 2005; Shi and Manning, 2009; Timmers, 1998). The business model concept is used superficially as a reference to how companies do business, and as a model, i.e. to analyze and reduce complexity. Many scholars argue that the business model consists of components that are put together, and which also define the business model concept (Chesbrough and Rosenbloom, 2002; Osterwalder, 2004). One significant difference exists in the view of 
strategy and business model. Some researchers include strategy as a component of the business model (Chesbrough and Rosenbloom, 2002; Hamel, 2001; Timmers, 1998). Others describe the concepts as being linked i.e. interrelated, but that a distinct difference exists, which means that the business model is about system functions and roles while the strategy includes competition and performance (Magretta, 2002; Mansfield and Fourie, 2004).

In this context, some years ago two publications appeared that aimed to explain the components of the business model, one by Osterwalder et al. (2005) and one by Morris et al. (2005). Osterwalder et al. (2005) provided an ontological description of the business model components. From a literature study, nine components that form the basis of the business model are presented. A central idea is that all the elements that can be linked to competition, implementation, and execution are separate from the business model. The reason is that many researchers describe business models as being more or less successful, which Osterwalder $e t$ al. (2005) consider to be an incorrect approach. A seemingly "strong" business model that has shortcomings in implementation and execution may fail, while a "weak" one can succeed with the help of strong leadership. Thus, analysis of business model and strategy should be separate.

The business model concepts of Morris et al. (2005) overlap relatively much with Osterwalder's et al. (2005) model; the components are similar in content. An important difference is that Morris et al. include competitive strategy. In addition, the model includes the owner/manager's personal ambitions. Since the present study examines where in the business model entrepreneurship exists, and not whether it is successful or not, the business model of Morris et al. becomes relevant as an analytical tool. As the entrepreneur's personal ambitions are affected by the environment that he or she works in, there is also a link to the place where he or she operates, which also makes the above model appropriate. 
The business model of Morris et al. (2005) is described by six components or decision areas. These components exist in every company and consist of the following: Offer, Market, Economy, Personal Factors, Internal Capability, and Competitive Strategy. The Offer explains how the company creates value, its role in the production, and how the offer is configured. The Market component describes the company's customers; are these consumers or other businesses? In addition, it defines the company's position in the value chain. Economy refers to the company's sources of revenue, and is the core of the business model. The economic factor can be understood/investigated by the ratio between fixed and variable costs, small or large production volumes, low or high margins, pricing, and the company's flexibility in revenue sources. Personal Factors concern the entrepreneur's ambitions in terms of time and growth. Is the entrepreneur just interested in a moderate but stable income or is the entrepreneur seeking growth and expansion? Such conditions are reflected in the business model. The Internal Capability describes the company's expertise and skills, which may involve product development, innovation, marketing, finance, and logistics. Competitive Strategy means how the company is positioned in the market. For instance, does the strategy build on low pricing, differentiation, or intimate customer relationships?

In order to capture the complexity and improve the business model as an analytical tool, each of the components is analyzed at three different decision levels. These are called ground level, business level, and rule level (Morris et al., 2005). The ground level specifies what kind of business and activities the company should have or not have, which makes internal consistency possible. Examples of ground-level decisions are which customers to sell to and how to choose to segment the market. At the business level, the model concerns how factors such as products, distribution channels, small and large volumes, high or low margins, and human capital are combined. At this level, the business model could be used as a tool to create value within the six components, as well as for the whole company. The rule level considers 
operational guidelines. Ground-level and business-level decisions are translated and implemented through concrete rules and policies that reflect the ongoing strategic work.

\section{Entrepreneurial Orientation in the Various Components of the Business Model}

The six components of the business model are often interrelated, and many companies can be highly entrepreneurial in several of the dimensions. Also, in order for a company to achieve a competitive advantage as a result of its entrepreneurial activities in one dimension, it can also require the business to be entrepreneurial in other dimensions. However, to start with we will describe how EO can be manifested in the various dimensions separately.

\section{The Offer component—Entrepreneurial value propositions}

By being entrepreneurial in the Offer component of the business model, a company is innovative in its value propositions. We will use the phenomenon that business-to-business manufacturing companies are selling more and more services linked to their products (Jacob and Ulaga, 2008) as an example of how firms can be entrepreneurial in their offer. The pioneers of each industry to make the transition from selling mainly goods to increasing the service dimensions of their offer are examples of firms that have acted entrepreneurially by being innovative, proactive, and risk-taking by introducing new offerings. The transition from only offering tangible goods to offering more services sometimes requires firms to develop internal capabilities and to adjust other areas of the business model (Brax, 2005). However, most manufacturing firms generally offer services in conjunction with their tangible goods. Selling more services can, in many cases, only require a reorientation of the business. This will only require the firm to adjust its existing processes and not, for example, its capabilities or other factors of the business model (Oliva and Kallenberg, 2003). Also, although other alterations in the business model are necessary, the transition from goods to services is often 
initialized by awareness in the "offer factor", i.e. the need to reorient the offer to give more services (Gebauer et al., 2005).

The discussion regarding the transition from goods to services is an example of how firms can be entrepreneurial by introducing a new value offer in the market. The first firms in an industry to outsource production to new regions or the first firms to adopt a mass customization strategy are other examples of firms that are mainly entrepreneurial in this component of the business model.

\section{The Market component-Entrepreneurial market and customer selection}

By being entrepreneurial in the marketing component, firms break the existing patterns of their industry by redefining existing customers and markets or by identifying new customers and markets. Entrepreneurial marketing (Morris et al., 2002; Stokes, 2000) is a concept that has been used to describe firms that are entrepreneurial in a marketing context. However, although the literature on entrepreneurial marketing usually takes opportunity recognition in the product market as a point of departure, the concept is quite broad—ranging from activities such as opportunity recognition to resource management, management structure (Hills et al., 2007; Morris et al., 2002), and alliance management (Sarkar et al., 2001). Thus, entrepreneurial marketing usually refers to more components of the business model than the market factor. However, firms can also be innovative, risk-taking, and proactive solely in the market component of the business model.

For example, many SMEs are often reluctant to internationalize their business (Westhead et $a l ., 2001)$ and in some industries exporting of products can be a highly entrepreneurial task (Ibeh, 2003). As illustrated in the ample numbers of studies on international entrepreneurship (Coviello and Jones, 2004; Jones et al., 2011; McDougall and Oviatt, 2000), exportation of products is often associated with elements of risk - and for the first-mover, by definition, 
proactivity and innovation. Another example of EO in the market component is firms that are entrepreneurial in their value chain management by, for example, overstepping several levels in the value chain. Thus, by selling products to new customers or by launching existing products in new markets, firms can be entrepreneurial in the market component of the business model.

\section{The Economic component-Entrepreneurial pricing}

The economic component of the business model mostly concerns the pricing of products. Most other dimensions of the economic component of the business model, for example cost management and operation leverage, generally require firms to be highly methodological and to systematically develop and improve their routines. The pricing of products, however, can be a potential avenue for highly entrepreneurial approaches. Schindehutte and Morris (2001, p.43) defines entrepreneurial pricing as "pricing that is market-based, risk-assumptive, proactive, and flexible". Thus, pricing can be regarded as an entrepreneurial activity and there are several indications that pricing is becoming a more and more important aspect of management. Schindehutte and Morris (2001, p.42) provide a good example of the importance of pricing: "Consider any five people on a given airline flight. The likelihood is that each is paying a different amount to get from Point A to Point $\mathrm{B}$, and it has nothing to do with the airline's costs of providing that flight". Also, the introduction of new technology in terms of, for example, new or multiple-distribution channels and the increased accessibility to information about prices make pricing issues more complex and important (Tang and Xing, 2001). This will, however, also result in new opportunities and firms that are more risktaking, innovative, and proactive in their pricing practices can be benefit from this complexity (Pitt et al., 1997). 


\section{The Personal factor component-Entrepreneurial in core ambitions}

Personal factors such as growth ambitions and the core reason for being involved in a company are always reflected in other aspects of the business model. Nevertheless, some personal factors per se can also be regarded as being highly entrepreneurial. For example, numerous studies (Habbershon and Williams, 1999) have shown that family-owned firms generally take less risks (Naldi et al., 2007) and focus more on long-term stability than nonfamily firms (Chirico et al., 2011). Whether or not the owner(s) regard their business as a family affair that transcends generations or if they see their business as a short-term investment with a well-planned exit strategy (Headd, 2003) will obviously have great impact on the business strategy and the propensity to take risks. Thus, differences in EO that can be explained by personal factors have mainly been analyzed by comparing family firms and nonfamily firms (Kellermanns and Eddleston, 2006). However, core ambitions are likely to have a great impact on all firms; and for some firms, this component of the business model is likely to be the origin of other entrepreneurial activities. Big decisions such as when to invest, when to harvest, when or if to exit, etc. can often be explained by personal factors. For example, the core ambitions of the founders of companies such a Facebook, Spotify, and Google were to build world-leading companies. If these companies had focused on profit maximization in terms of, for example, extensive advertising at an early stage, it is highly questionable whether these companies would have achieved such success. A new company with an owner with the core ambition to grow and be competitively aggressive in an industry dominated by family-owned firms focusing on stability and longevity is another example of entrepreneurial core ambitions.

This does not mean that the absence or presence of entrepreneurship can always be reduced to personal factors. The core ambitions can, of course, also be the same, and the companies in an 
industry can differ in their methods of achieving this ambition by being entrepreneurial (or conservative) in other components of the business model.

\section{The Internal Capability component-Entrepreneurial resource management}

Whereas most entrepreneurial activities in the other components of the business model can be imitated by competitors, entrepreneurial actions regarding resources and capabilities are often more difficult to imitate. To be innovative in factor markets in order to build capabilities or to acquire strategic resources is a key element of the resource-based view (Barney, 1991; Wernerfelt, 1984). Thus, by being entrepreneurial regarding, for example, recruitment of personnel with specific capabilities or by implementing some specific training programs to build capabilities, firms can develop strategically important resources (Godfrey and Gregersen, 1999). These capabilities are generally socially complex and require a long period of time to develop, which makes them difficult to imitate (Barney, 1991). Thus, whereas, for example, entrepreneurial product market positioning, entrepreneurial value propositions, or (especially) entrepreneurial pricing require the company to be entrepreneurial on a more continuous basis, the result of entrepreneurial resource management can often result in more sustainable competitive advantages (Andersén, 2007).

Being entrepreneurial in the internal development of capabilities usually takes a long time and - in addition to the traditional elements of EO (i.e. risk-taking, innovativeness, and proactivity) - managers of these companies also have to possess some degree of perseverance (Markman et al., 2004). However, firms can also be entrepreneurial in the capability component of the business model by, for example, forming alliances and collaborations with other firms or organizations. The result of these collaborations can generate new combinations of knowledge, thus resulting in new capabilities. An important rationale for collaboration and alliance is to share resources (Andersén and Kask, 2012; Das and Teng, 2000), and Sarkar et 
al. (2001) found that firms that are entrepreneurial in their alliance management in volatile markets generally outperform their competitors.

\section{The Competitive Strategy component-Entrepreneurial product market positioning}

How a firm positions the products in the current product market can also be an avenue for entrepreneurial actions. From a resource-based view, the possibilities in the choice of product market strategy are restricted by the resources the company possesses (Barney, 1991). For example, if a firm intends to position its products as low-price products in order to gain market share, it must have the low-cost production capabilities to produce these products. Nevertheless, firms can identify an opportunity in the product market and thereafter acquire the resources required to implement the strategy. Also, by implementing a new risk-taking competitive strategy, a firm can gain several first-mover advantages. For example, the first company to differentiate its products by focusing more on branding in a traditionally nonbrand-intensive industry can set the standard for the industry (Kerin et al., 1992). Thus, firms can be entrepreneurial in their efforts to position their products in the product market by implementing various entrepreneurial strategies. These strategies generally require the firm to alter other components of the business model. Thus, the actions of risk-taking, innovativeness, and proactivity are undertaken in the product market in the sense that the firm implements a new (for the existing industry) competitive strategy. For example, a firm that is entrepreneurial in its resource management takes the risk by making entrepreneurial investments in its resources and - if necessary — then implements a new competitive strategy. On the other hand, firms that are entrepreneurial in their product market positioning identify the opportunity and take the (initial) risk etc. in the product market, and alter other components based on this decision. 


\section{Illustrative Cases}

So far, we have discussed EO in the various components of the business model separately. In practice, firms are generally entrepreneurially oriented in several components. However, the entrepreneurial activity is often initialized in a specific component of the business model and followed by adjustments in other components. In this section, we describe some illustrative cases of these processes, i.e. how the entrepreneurial activity is initialized, and its consequences. As our cases illustrate, EO can be present in various components of the business model and the characterization of EO differs significantly depending on where the entrepreneurial activity is initialized. The empirical illustrations have two sources of data: annual reports and interviews with mainly owner/managers of the SMEs. The cases are described in more detail in previous studies (i.e. Andersén, 2005; Ljungkvist, 2008; Svensson, 2012). The purpose of these short case descriptions is to illustrate the usefulness of applying a business model approach in order to understand EO from a more holistic standpoint. The cases are summarized in Table 1 .

\section{Insert Table 1 here}

Centiro Solutions is a software and consultancy firm. All other firms are manufacturing companies. The data presented in Table 1 are from the period 2009-2011 for Centiro, Mann Teknik and Hermanders. The information regarding Formia and Ojop is from the period 1997-2001. All figures, i.e. size in terms of numbers of employees, profitability in terms of return on assets, and growth measured as average annual increase in turnover) is the average for the period described. 


\section{Centiro Solutions Ltd.}

The software company Centiro Solutions was founded in 1998. The company specializes in development of component-based software for transportation and logistics solutions in modular form. The company was founded based on the owner/manager's knowledge and innovation capacity in logistics and software. From his own experience and skills, he created the company's first software. In this way, the entrepreneurship in Centiro Solutions was initiated in the component Internal Capability. The company's competition strategy is characterized by differentiation. In this industry, Centiro Solutions regard themselves as one of the five best in the world. The goal is to be the "best" in the industry, which means that they never compete on price; instead, they focus on quality and custom-designed solutions. The company's market, which is business to business, is international and the share of foreign customers is growing. For example, Centiro Solutions has international companies such as DNT, Schenker, and Apple as customers. The company has an outspoken growth ambition, which is visualized in the concept of "staying ahead of the growth curve". The company is generally investing more in equipment and buildings than the current needs. This facilitates both national and international expansion.

The personal ambitions of the owner/manager and also the firm's market- and competitive strategies can be regarded as highly entrepreneurial. It is, however, evident that the entrepreneurial actions were initialized by the internal capabilities of the owner/manager and that the other entrepreneurial activities originated from the internal capabilities of the firm.

\section{Mann Teknik Ltd.}

The company Mann Teknik Ltd. started in 1994 and it is established on the world market. Mann Teknik is one of four producers of environmentally friendly couplings for the aviation industry and the gas and oil industry. The start of the company came from the concept and 
development of couplings for transportation of liquids, and the founder of the company was the designer of improvements in the product. The company has continually refined the product and today it is sold in more than 30 countries. The company identified an attractive niche in the product market at an early stage and developed the business around this specific competitive niche strategy. As a consequence of this competitive strategy, Mann Teknik began to focus on an extensive internationalization strategy by launching products on highly insecure markets. The closeness to the market is important, and the sellers travel for long periods and come home with knowledge and direct contacts from the customers and the production, so the "market intelligence" — knowledge about the target market—comes directly to the owners and the production team.

Although the company has important internal capabilities and a successful pricing strategy, Mann Teknik is quite conservative in these components of the business model. The entrepreneurial actions were, however, initialized in the Competitive Strategy component by identification of a profitable niche. The results of this competitive strategy were more entrepreneurial actions in the product market by the risk-taking strategy of launching the products on various insecure markets.

\section{Hermanders Ltd.}

The metal-spinning company Hermanders Ltd. was founded in 1991 by the current owners/managers of the company and a co-worker. The company specializes in production of different products in metal, mainly by using the so-called spinning technique. The products can be lamps or items for aircraft, among other things. The founders started the company in order to use their highly developed innovative capabilities and thereby develop the metalspinning technique. The company changed from manual production to industrial and mechanized production, and managed to develop the necessary capabilities in the employees 
in order to realize this transition. In order to achieve this goal (i.e. the change from manual to mechanized production), the company also placed its customer's molds and tools in its own factory. Also, Hermanders acquired other companies and moved these companies' production to its own plant.

To summarize, the company was highly entrepreneurial by developing its internal capabilities. As a result, it also acted entrepreneurially by making some groundbreaking alterations in the Offer component of the business model by acquisition of other companies, and by placing customers' tools and molds in its own plant to a greater extent than its competitors.

\section{Ojop Sweden Ltd.}

The company was founded as early as 1922 , and it manufactures battery connectors and socalled catchers and strikers. When a new owner/manager entered the company, Ojop began to refocus its business by an extensive internationalization strategy. In a short period of time, the company increased its exports from less than $50 \%$ to over $85 \%$. The owner/manager himself has more than 100 travel days a year and is extremely focused on creating and developing relationships with the company's customers, which include retailers such as Wal-Mart. The products that are produced are not very complex; however, by focusing on sales and relationship building, the company has been highly profitable. In order to strengthen its customer relationship, Ojop has also implemented a more market-oriented pricing strategy.

Thus, Ojop was initially highly entrepreneurial in the Market component by adopting a highly outward-looking strategy, characterized by internationalization. In the course of time, when the relationships were established, the company began to focus on strengthening these relationships, thus being entrepreneurial in the Economic component and in the Competitive Strategy component. The novelty of the latter component is the fact that the owner/manager focused so much on personal relationships directly with customers. 
Formia was acquired by a new owner in 1982. The company produces molding tools for other manufacturing companies, and at the time of the acquisition was a traditional craftsmanship company. The new owner had a vision of developing a company that could produce unique tools by using modern serial production techniques. This ambition was new to the industry and the core ambition of the owner can thus be regarded as highly entrepreneurial. In order to realize this vision, the company began to recruit highly skilled personnel and to invest in (at the time) advanced production facilities. When the company had managed to accomplish the ambition of mass producing unique tools, it also changed its competitive strategy from "selling everything to everybody, to focusing on complex tools that were sold to a few profitable customers"-for example, Nokia. The number of customers was reduced from 55 to 8 .

Formia was highly entrepreneurial in its resource management by its development of internal capabilities and was somewhat entrepreneurial by adopting a focus-based competitive strategy. However, the entrepreneurial actions were initialized by personal factors related to the owner of the company. The vague vision of serial production of unique tools was regarded as foolish by many others in the industry at the time, and many in the industry considered it to be an impossible task.

\section{Discussion}

The main contribution of this article is that it directs attention to the fact that entrepreneurship can take place in various areas in a company, and that it illustrates that established business models can be used to identify and analyze various forms of entrepreneurship. Whereas previous studies on EO have focused on the concept of entrepreneurship as a generic type of management or have been restricted to external activities, this article provides a more 
complex and multifaceted picture of EO. Using a business model approach has three main contributions to strategic entrepreneurship theory by: (1) allowing a more practice-oriented approach to entrepreneurship, (2) highlighting the importance of identifying different antecedents to $E O$, and (3) encouraging other researchers to examine the relationship between EO and firm performance by analyzing EO at the component level. We will now address these implications, and we will also discuss the limitations of the study and provide some suggestions for future research.

\section{A practice-oriented approach}

Using a business model approach to entrepreneurship can make the EO concept more realistic and closer to practice. Thus, applying a business model approach can allow the use of a more inductive method that is less restricted to specific theories or viewpoints. For example, RBV approaches will generally take the entrepreneurial actions in resource investments as their point of departure and regard the implementation of a new market strategy as being a result of these new resources. From an entrepreneurial marketing point of view, however, this would most likely be explained by an opportunity recognized in the product market and by the resources being acquired in order to seize this opportunity. The success of most companies in our illustrative cases can be explained by solely applying a resource-based view or competitive strategy approach. However, by analyzing the companies from various components of the business model, the key component or components can be identified. For example, the company Formia could be classified as being entrepreneurial in the development of its internal capabilities and also as being entrepreneurial by using a focus-based competitive strategy. However, these actions were only the consequence of the personal ambitions of the owner, and it was these ambitions that made the company unique and highly entrepreneurial. 
As illustrated by our cases, it is seldom enough that a company should be entrepreneurial in only one component of the business model. Even so, the entrepreneurial activity is often initialized in a specific component. If we did not use a business model approach, we would risk overlooking other important components of the business model. Thus, it is important to identify the factor in which the change started, i.e. in which the opportunity was recognized. An important reason for identifying the component in which the entrepreneurship is initialized is that antecedents to EO are likely to vary depending on where the entrepreneurship is initialized.

\section{Various antecedents to EO}

Identification of antecedents to EO is an important area of research (Kreiser et al., 2002; Rutherford and Holt, 2007). However, it is highly plausible that antecedents to EO can vary quite significantly depending on which components of the business model the company is entrepreneurially oriented in. Our cases provide a good illustration of this. Although all managers could be classified as being highly entrepreneurial in some areas, the viewpoints of these entrepreneurs were very different. Some entrepreneurs (e.g. the owner of Hermanders) were mostly interested in developing the capabilities in order to produce innovative, complex, and/or high-quality products, and took great risks in their resource investment, i.e. training, recruitment, investment in new technology etc. Other entrepreneurs (the owners of Ojop and Mann Teknik) focused on making the most of their existing capabilities and products by finding the ideal markets or market positions for their products. These companies could be classified as being highly entrepreneurial regarding their endeavors in the product market. Thus, different firms are likely to have different abilities to recognize opportunities in various components of the business model. Also, and as illustrated by our cases, the propensity to be entrepreneurial in different components is likely to differ between firms. In our illustrative cases, no company was entrepreneurial in all dimensions of the business model. Instead, all 
the companies were highly entrepreneurial in certain components of the business model but quite conservative and conventional in the other components. Thus, it is highly likely that the antecedents to the various forms of entrepreneurship differ between firms.

\section{(Deconstructed) EO and firm performance}

The relationship between EO and the performance of firms has always been the main area of interest in research on EO. Although some authors have identified a positive relationship between EO and performance (Lumpkin and Dess, 1996; Wiklund and Shepherd, 2003), others have questioned this relationship (Andersén, 2010) and several studies have failed to identify a positive relationship (e.g. Hughes and Morgan, 2007; Slater and Narver, 2000). By deconstructing EO — i.e. by analyzing it as various components of the business model - the relationship between different forms of $\mathrm{EO}$ and performance might be less ambiguous. For example, it is conceivable that being entrepreneurial in certain components is more profitable than being entrepreneurial in other components. These issues can, of course, be analyzed in various contexts and different moderating variables are likely to have different influences on the relationship depending on the component in which a firm is entrepreneurial.

The established definition of EO is not applicable when analyzing EO using a business model approach. In order to measure EO in various components of the business model, new scales must be developed. It also plausible that some of the components may be more interrelated than others, and it might not be necessary to reduce the concept of EO to all the components proposed by Morris et al. (2005). This issue has not been addressed in the present article, and this leads us to the proposals for future research and to the limitations of the present article.

\section{Future research and limitations}

We have already addressed the first limitation and proposal for future research (i.e. to analyze the relationship between EO in various business model components and performance). In this 
article, we have not addressed the issue of operationalizing EO in various components and this is an important area for future research. Relating EO to performance is an important task and our (re)definition of EO is no exception. Although it might be a difficult task to simultaneously measure EO in all components of the business model, it could be constructive to measure some specific components.

Another limitation of this article is that we have used a single business model, i.e. the model developed by Morris et al. (2005), in order to analyze EO. Although this is an established model and although we argued for the usefulness of this particular model in the business model section of this article, there are other methods to describe and define business models. As argued in this article, a business model approach to entrepreneurship can be very useful. It would therefore make sense to compare and test different business model conceptualizations and their usefulness for studying entrepreneurship in future studies.

Although we provide some illustrative cases, this article is mainly a conceptual articlewhich might be regarded as a limitation. We need more empirical studies (both crosssectional studies and case studies) in order to understand which components of the business model it is most common to be entrepreneurial in. Also, empirical studies can provide better knowledge of the various pros and cons of using a business model approach when studying EO. 


\section{Conclusion}

Whereas contemporary research on EO has concentrated on the level of entrepreneurship at a generic or external level, this article has provided some arguments for deconstruction of the concept of EO by analyzing entrepreneurship in terms of different components of the business model. A firm can be highly entrepreneurial in some components and conservative in others. For example, at first glance, a company such as Formia would most likely be regarded as a conservative company reluctant to undergo change and renewal due to its lack of a proactive and aggressive market strategy. However, if one analyzes this company in more detail, it becomes evident that the company was extremely entrepreneurial in its heavy investments in human and technological resources. Regarding OJOP, it was highly entrepreneurial in product development and marketing and would therefore be defined as very entrepreneurial when classified according to established EO scales. However, the company was quite conservative in its resource investments and other areas of business.

This deconstruction of EO is likely to have some important consequences. Most importantly, the relationship between EO and performance and variables that moderate this relationship will probably differ depending on which component of the business model a firm is entrepreneurial in. As illustrated by our cases, few companies are likely to be entrepreneurial in all components of the business model, and it would be very interesting to examine the EOperformance relationship from a more deconstructed approach. In doing so, it would be possible to identify the components of the business model in which it is most profitable to act entrepreneurial in. Also, the antecedents of entrepreneurship are likely to differ between the various components of the business model. Entrepreneurs will most probably differ significantly in their abilities to recognize opportunities in the various components of the business model. Also, and illustrated by our cases, their attitudes to change in the different components are different, and entrepreneurs are likely to be open to change in some 
components but are likely to be reluctant when it comes to altering other parts of their businesses.

The most important argument in this article is that we should redirect our attention in entrepreneurship research from the question "how much?" to the question "where?". This study has only ascertained that there are several advantages to applying a business model approach to entrepreneurship. It will hopefully encourage other researchers to examine these issues further and in more detail.

\section{References}

Andersén, J. (2005) Strategiska resurser och långvarig lönsamhet: en resursbaserad modell för varaktiga konkurrensfördelar i små tillverkningsföretag, School of Business, Mälardalen University, Västerås, Sweden.

Andersén, J. (2007), "How and what to imitate? A sequential model for the imitation of competitive advantages ", Strategic Change, Vol. 16 No. 6, pp. 271-79.

Andersén, J. (2010), "A critical examination of the EO-performance relationship", International Journal of Entrepreneurial Behaviour \& Research, Vol. 16 No. 4, pp. 309-28.

Andersén, J. and Kask, J. (2012), "Asymmetrically realized absorptive capacity and relationship durability", Management Decision, Vol. 50 No. 1, pp. 43-57.

Barney, J.B. (1991), "Firm resources and sustained competitive advantage", Journal of Management, Vol. 17 No. 1, pp. 99-120.

Brax, S. (2005), "A manufacturer becoming service provider-challenges and a paradox", Managing Service Quality, Vol. 15 No. 2, pp. 142-55.

Chesbrough, H. and Rosenbloom, R.S. (2002), "The role of the business model in capturing value from innovation: evidence from Xerox Corporation's technology spin-off companies", Industrial and Corporate Change, Vol. 11 No. 3, pp. 529-55.

Chirico, F., Sirmon, D.G., Sciascia, S. and Mazzola, P. (2011), "Resource orchestration in family firms: investigating how entrepreneurial orientation, generational involvement, and participative strategy affect performance", Strategic Entrepreneurship Journal, Vol. 5 No. 4, pp. 307-26.

Coviello, N.E. and Jones, M.V. (2004), "Methodological issues in international entrepreneurship research", Journal of Business Venturing, Vol. 19 No. 4, pp. 485-508.

Covin, J.G., Green, K.M. and Slevin, D.P. (2006), "Strategic process effects on the entrepreneurial orientation-sales growth rate relationship", Entrepreneurship Theory and Practice, Vol. 30 No. 1, pp. 57-81. 
Covin, J.G. and Slevin, D.P. (1989), "Strategic management of small firms in hostile and benign environments", Strategic Management Journal, Vol. 10 No. 1, pp. 75-87.

Covin, J.G. and Slevin, D.P. (2007), "The influence of organization structure on the utility of an entrepreneurial top management style", Journal of Management Studies, Vol. 25 No. 3, pp. 217-34.

Covin, J. G. and Wales, W. J. (2012), "The measurement of entrepreneurial orientation", Entrepreneurship Theory and Practice, Vol. 36 No. 4, pp. 677-702.

Das, T.K. and Teng, B.S. (2000), "A resource-based theory of strategic alliances", Journal of Management, Vol. 26 No. 1, pp. 31.

Dess, G.G., Lumpkin, G.T. and Covin, J.G. (1997), "Entrepreneurial strategy making and firm performance: Tests of contingency and configurational models", Strategic Management Journal, Vol. 18 No. 9, pp. 677-95.

Gebauer, H., Fleisch, E. and Friedli, T. (2005), "Overcoming the service paradox in manufacturing companies", European Management Journal, Vol. 23 No. 1, pp. 14-26.

George, G. and Bock, A.J. (2011), "The business model in practice and its implications for entrepreneurship research", Entrepreneurship Theory and Practice, Vol. 35 No. 1, pp. 83-111.

Godfrey, P.C. and Gregersen, H.B. (1999), "Where do resources come from? a model of resource generation", Journal of High Technology Management Research, Vol. 10 No. 1, pp. 37-60.

Habbershon, T.G. and Williams, M.L. (1999), "A resource-based framework for assessing the strategic advantages of family firms", Family Business Review, Vol. 12 No. 1, pp. 1-25.

Hamel, G. (2001), Leading the revolution, Harvard Business School Press, Boston, MA.

Headd, B. (2003), "Redefining business success: distinguishing between closure and failure", Small Business Economics, Vol. 21 No. 1, pp. 51-61.

Hills, G.E., Hultman, C.M. and Miles, M.P. (2007), "The evolution and development of entrepreneurial marketing", Journal of Small Business Management, Vol. 46 No. 1, pp. 99-112.

Hughes, M. and Morgan, R.E. (2007), "Deconstructing the relationship between entrepreneurial orientation and business performance at the embryonic stage of firm growth", Industrial Marketing Management, Vol. 36 No. 5, pp. 651-61.

Ibeh, K.I.N. (2003), "Toward a contingency framework of export entrepreneurship: conceptualisations and empirical evidence", Small Business Economics, Vol. 20 No. 1, pp. 4968.

Jacob, F. and Ulaga, W. (2008), "The transition from product to service in business markets: an agenda for academic inquiry", Industrial Marketing Management, Vol. 37 No. 3, pp. 247-53.

Jones, M.V., Coviello, N. and Tang, Y.K. (2011), "International Entrepreneurship research (19892009): a domain ontology and thematic analysis", Journal of Business Venturing, Vol. 26 No. 6, pp. 632-59.

Kellermanns, F.W. and Eddleston, K.A. (2006), "Corporate entrepreneurship in family firms: a family perspective", Entrepreneurship Theory and Practice, Vol. 30 No. 6, pp. 809. 
Kerin, R.A., Varadarajan, P.R. and Peterson, R.A. (1992), "First-mover advantage: a synthesis, conceptual framework, and research propositions", Journal of Marketing, Vol. 56 No. 4, pp. 33-52.

Kreiser, P.M., Marino, L.D. and Weaver, K.M. (2002), "Assessing the psychometric properties of the entrepreneurial orientation scale: a multi-country analysis", Entrepreneurship Theory and Practice, Vol. 26 No. 4, pp. 71-94.

Lumpkin, G.T. and Dess, G.G. (1996), "Clarifying the entrepreneurial orientation construct and linking it to performance", Academy of Management Review, Vol. 21 No. 1, pp. 135-72.

Ljungkvist, T. (2008), Affärsrådgivning: samspel mellan entreprenör och experter, School of Business Economics and Law, University of Gothenburg, Gothenburg, Sweden.

Magretta, J. (2002), "Why business models matter", Harvard Business Review, Vol. 80 No. 5, pp. 8693.

Mansfield, G. and Fourie, L. (2004), "Strategy and business models-strange bedfellows? a case for convergence and its evolution into strategic architecture", South African Journal of Business Management, Vol. 35 No. 1, pp. 35-44.

Markman, G.D., Baron, R.A. and Balkin, D.B. (2004), "Are perseverance and self-efficacy costless? assessing entrepreneurs' regretful thinking", Journal of Organizational Behavior, Vol. 26 No. 1, pp. 1-19.

McDougall, P.P. and Oviatt, B.M. (2000), "International entrepreneurship: the intersection of two research paths", Academy of Management Journal, Vol. 43 No. 5, pp. 902-06.

Miller, D. and Friesen, P.H. (1982), "Innovation in conservative and entrepreneurial firms: two models of strategic momentum", Strategic Management Journal, Vol. 3 No. 1, pp. 1-25.

Morris, M., Schindehutte, M. and Allen, J. (2005), "The entrepreneur's business model: toward a unified perspective", Journal of Business Research, Vol. 58 No. 6, pp. 726-35.

Morris, M.H., Schindehutte, M. and LaForge, R.W. (2002), "Entrepreneurial marketing: a construct for integrating emerging entrepreneurship and marketing perspectives", Journal of Marketing Theory and Practice, Vol. 10 No. 4, pp. 1-19.

Naldi, L., Nordqvist, M., Sjöberg, K. and Wiklund, J. (2007), "Entrepreneurial orientation, risk taking, and performance in family firms", Family Business Review, Vol. 20 No. 1, pp. 33-47.

Oliva, R. and Kallenberg, R. (2003), "Managing the transition from products to services", International Journal of Service Industry Management, Vol. 14 No. 2, pp. 160-72.

Osterwalder, A. (2004), The business model ontology: A proposition in a design science approach, Institut d'Informatique et Organisation. University of Lausanne, Ecole des Hautes Etudes Commerciales HEC, Lausanne, SZ.

Osterwalder, A., Pigneur, Y. and Tucci, C.L. (2005), "Clarifying business models: origins, present, and future of the concept", Communications of the Association for Information Systems, Vol. 16 No. 1, pp. 1-25.

Pearce, I., John, A., Fritz, D.A. and Davis, P.S. (2009), "Entrepreneurial orientation and the performance of religious congregations as predicted by rational choice theory", Entrepreneurship Theory and Practice, Vol. 34 No. 1, pp. 219-48. 
Pitt, L.F., Berthon, P.R. and Morris, M.H. (1997), "Entrepreneurial pricing: the Cinderella of marketing strategy", Management Decision, Vol. 35 No. 5, pp. 344-50.

Rutherford, M.W. and Holt, D.T. (2007), "Corporate entrepreneurship: an empirical look at the innovativeness dimension and its antecedents", Journal of Organizational Change Management, Vol. 20 No. 3, pp. 429-46.

Sarkar, M.B., Echambadi, R.A.J. and Harrison, J.S. (2001), "Alliance entrepreneurship and firm market performance", Strategic Management Journal, Vol. 22 No. 6-7, pp. 701-11.

Schindehutte, M. and Morris, M.H. (2001), "Pricing as entrepreneurial behavior", Business Horizons, Vol. 44 No. 4, pp. 41-48.

Shafer, S.M., Smith, H.J. and Linder, J.C. (2005), "The power of business models", Business Horizons, Vol. 48 No. 3, pp. 199-207.

Shi, Y. and Manning, T. (2009), "Understanding business models and business model risks", The Journal of Private Equity, Vol. 12 No. 2, pp. 49-59.

Slater, S.F. and Narver, J.C. (2000), "The positive effect of a market orientation on business profitability: a balanced replication", Journal of Business Research, Vol. 48 No. 1, pp. 69-73.

Smart, D.T. and Conant, J.S. (1994), "Entrepreneurial orientation, distinctive marketing competencies and organizational performance", Journal of Applied Business Research, Vol. 10 No. 3, pp. 2838.

Stokes, D. (2000), "Putting entrepreneurship into marketing: the processes of entrepreneurial marketing", Journal of Research in Marketing and Entrepreneurship, Vol. 2 No. 1, pp. 1-16.

Svensson, L. (2012), Platsen som resurs för små och medelstora företag, School of Business Economics and Law, University of Gothenburg, Gothenburg, Sweden.

Tang, F.F. and Xing, X. (2001), "Will the growth of multi-channel retailing diminish the pricing efficiency of the web?", Journal of Retailing, Vol. 77 No. 3, pp. 319-33.

Timmers, P. (1998), "Business models for electronic markets", Electronic Markets, Vol. 8 No. 2, pp. 38.

Wernerfelt, B. (1984), "A resource-based view of the firm", Strategic Management Journal, Vol. 5 No. 2, pp. $171-80$.

Westhead, P., Wright, M. and Ucbasaran, D. (2001), "The internationalization of new and small firms: a resource-based view", Journal of Business Venturing, Vol. 16 No. 4, pp. 333-58.

Wiklund, J. and Shepherd, D. (2003), "Knowledge-based resources, entrepreneurial orientation, and the performance of small and medium-sized businesses", Strategic Management Journal, Vol. 24 No. 13, pp. 1307-14.

Voss, Z.G., Voss, G.B. and Moorman, C. (2005), "An empirical examination of the complex relationships between entrepreneurial orientation and stakeholder support", European Journal of Marketing, Vol. 39 No. 9/10, pp. 1132-50.

Zahra, S.A. (1991), "Predictors and financial outcomes of corporate entrepreneurship: An exploratory study", Journal of Business Venturing, Vol. 6 No. 4, pp. 259-85. 
Zott, C. and Amit, R. (2008), "The fit between product market strategy and business model: implications for firm performance", Strategic Management Journal, Vol. 29 No. 1, pp. 1-26. 